\title{
Application of prediction models of asian soybean rust in two crop seasons, in Londrina, $\mathrm{Pr}$
}

\section{Aplicação de modelos de previsão da ferrugem asiática da soja em duas safras agrícolas, em Londrina, $\mathrm{Pr}$}

\author{
Wagner Teigi Igarashi ${ }^{*}$; José Alexandre de França ${ }^{2}$; Marcelo Augusto de \\ Aguiar e Silva ${ }^{3}$; Seiji Igarashi ${ }^{3}$ Otávio Jorge Grigoli Abi Saab ${ }^{3}$
}

\begin{abstract}
Predictive models of Asian soybean rust have been described by researchers to estimate favorable responses to epidemics. The prediction strategies are based on weather data obtained during period when initial symptoms of the disease are observed. Therefore, this study will evaluate the application of two prediction models of Asian soybean rust, and compare the results from two harvest seasons. The experiments were carried out during the 2011/2012 and 2012/2013 seasons in Londrina, PR. "SIGA spore traps" were installed to monitor the presence of Phakopsora pachyrhizi uredospores, and "Electronic trees," to collect data on weather variables. Following the detection of the first urediniospores, incidence and disease severity were assessed and compared with the predictions made by the models. The model described by Reis et al. (2004) did not indicate favorable conditions for the development of the first rust lesions following the detection of the first urediniospores during the 2011/2012 season. The premonitory symptoms of rust in the first and second harvest seasons were observed only when the model of Reis et al. (2004) indicated SDVPI close to 15 units. The model of Del Ponte et al. (2006b) overestimated the final rust severity during the two seasons.
\end{abstract}

Key words: Disease simulation models. Electronic trees for wetness. Phakopsora pachyrhizi. SIGA spore trap.

\section{Resumo}

Modelos de previsão da ferrugem asiática da soja foram descritos por pesquisadores para estimar a favorabilidade climática para a ocorrência de epidemias. As estratégias de previsão estão fundamentadas em dados meteorológicos, a partir dos sintomas iniciais da doença. Portanto, objetivou-se aplicar dois modelos de previsão da ferrugem asiática da soja, e comparar com os resultados de duas safras agrícolas. A condução dos experimentos ocorreu nas safras 2011/2012 e 2012/2013 no município de Londrina, PR. Foram instalados "Coletores de esporos SIGA" para monitorar a presença de uredósporos de $P$. pachyrhizi, e "Árvores Eletrônicas de Molhamento" para coletar dados das variáveis meteorológicas. A partir da detecção dos primeiros uredósporos foram realizadas avaliações da incidência e da severidade da ferrugem, para comparar com as previsões feitas pelos modelos. O modelo de Reis et al. (2004) não indicou condições para o desenvolvimento das primeiras lesões da ferrugem após a chegada dos primeiros uredósporos na safra 2011/2012. Os primeiros sintomas da ferrugem na primeira e na segunda safra foram constatados apenas quando o modelo de Reis et al. (2004) indicou SVDPI próximo a 15

\footnotetext{
${ }^{1}$ Eng $^{\circ}$ Agr ${ }^{\circ}$, Dr., Departamento de Agronomia, Universidade Estadual de Londrina, UEL, Londrina, PR, Brasil. E-mail: wigarashi@ gmail.com

${ }^{2}$ Eng $^{\circ}$ Eletricista, Prof. Dr., Departamento de Eng ${ }^{a}$ Elétrica, UEL, Londrina, PR, Brasil. E-mail: josealexandre@uel.br

${ }^{3}$ Eng $^{\text {os }}$ Agr ${ }^{\circ s}$, Profs. Drs., Departamento de Agronomia, Universidade Estadual de Londrina, UEL, Londrina, PR, Brasil. E-mail: aguiaresilva@uel.br; seigarashi@gmail.com; abisaab@uel.br

* Author for correspondence
} 
unidades. O modelo de Del Ponte et al. (2006b) superestimou a severidade final da ferrugem-asiática nas duas safras.

Palavras-chave: Árvores Eletrônicas de Molhamento. Coletor de esporos SIGA. Modelos de simulação de epidemias. Phakopsora pachyrhizi.

\section{Introduction}

Asian soybean rust, caused by the fungus Phakopsora pachyrhizi Syd. \& P. Syd., was reported for the first time in Latin America in 2001 in Paraguay, and its presence was confirmed in Brazil in the same year in the west of Paraná State, and in 2002 in the states of Rio Grande do Sul, Mato Grosso do Sul, São Paulo, and Goiás (YORINORI et al., 2005). Since then, it has become one of the most important soybean diseases, requiring applications of fungicides to control harvest losses, subsequently increasing the cost of production (ITO et al., 2002; YORINORI, 2004).

In susceptible cultivars, the increase in severity of Asian rust during the growing season is determined by environmental factors, mainly temperature and leaf wetness (ALVES et al., 2006; BONDE et al., 2007; GARCÉS, 2011), which promotes epidemics. According to Del Ponte et al. (2007), the key elements of plant disease epidemics are the quantity of the inoculum and the season in which this reaches the crop or region, and the meteorological conditions during its arrival until the end of the culture cycle. These elements are substantiated in time and space during the presence of three determinant disease factors: host, pathogen, and favorable environment. For this reason, Gardiano et al. (2010) stated that chemical control programs of Asian rust should consider the preventive application of fungicides only after the point at which uredospores of $P$. pachyrhizi have been detected in the crop, and when the weather conditions are favorable.

Mathematical models can compare epidemics and distinguish varieties, treatments with fungicides, management techniques, and generate prediction models and assist in the quantification of damages and losses (BERGAMIN FILHO, 2011). Empirical disease predictive models for Asian rust showing suitable or critical periods for infection were proposed to estimate favorable climate conditions for the occurrence of epidemics (DEL PONTE et al., 2006a; DEL PONTE et al., 2006b; REIS et al., 2004). These models were obtained through linear and non-linear regression modeling techniques.

Reis et al. (2004) proposed a climate model based on data reported by Melching et al. (1989), in which the interaction between the temperature and leaf wetness duration (LWD) on the intensity of the disease, assessed by the number of rust lesions per $\mathrm{cm}^{-2}$, was presented in a tabular format. In this table, the model offers daily values of probability of infection (DVPI) of P. pachyrhizi, generating data of critical periods in which the infection can occur. Del Ponte et al. (2006b) developed a model using linear regression between the maximum or final severity of Asian rust epidemics, and meteorological variables collected during the development of the epidemics, after the disease was detected. Those authors found a higher correlation between final disease severity of Asian rust with rain than with temperature; the precipitation models explained 85 to $93 \%$ of the maximum disease severity. These forecasting strategies are based on weather data, from the period of initial disease symptoms.

The aim of the present study was to apply two forecasting models of Asian soybean rust (REIS et al., 2004; DEL PONTE et al., 2006b), using data from two harvest seasons in which the disease was observed.

\section{Material and Methods}

The field experiments were conducted in the 2011/12 and 2012/13 harvests, in the municipality of Londrina, in an experimental area of the Farm School of the Londrina State University (UEL), at a 
latitude of $23^{\circ} 34^{\prime} \mathrm{S}$, longitude $51^{\circ} 21^{\prime} \mathrm{W}$, and altitude of approximately $560 \mathrm{~m}$. The soil is classified as eutroferric Red Oxisol (EMBRAPA, 2009). The climate of the region is type Cfa according to the Köppen global climate classification, being humid subtropical with precipitation that is well distributed in all seasons. Droughts may occur in the winter period, with mean annual precipitation of 1,626 $\mathrm{mm}$ and annual mean temperature of $21.1^{\circ} \mathrm{C}$ (IAPAR, 2015).

The cultivar used in the two harvests was BMX Potência RR, with spacing of $0.45 \mathrm{~m}$ between rows and 18 plants per $\mathrm{m}^{-1}$, resulting in a population of 422,000 plants $\mathrm{ha}^{-1}$, in an area of direct planting preceded by wheat. Base fertilization at the time of sowing consisted of the application of $300 \mathrm{~kg} \mathrm{ha}^{-1}$ of the Formula 0-20-20 NPK. Sowing dates of the two crops were November 1, 2011 and October 26, 2012.

When the crop was at stage V4, four SIGA spore traps were installed (IGARASHI; BALAN, 2004; GARDIANO et al., 2010; IGARASHI et al., 2014), to determine when the first uredospore of $P$. pachyrhizi. The distribution was done in accordance with the prevailing wind direction, with two collectors on the east side and two in the middle of the experiment. The leaf wetness duration (LWD) was measured by the "Electronic tree" (MOREIRA et al., 2011; GUEDES et al., 2013), with 12 electronic wetness sensors distributed at three heights $(0.3 ; 0.6$, and 0.9 $\mathrm{m})$ representing the crop canopy, and the temperature and relative humidity of the air were measured in the same equipment at a height of $1.70 \mathrm{~m}$. Eight Electronic trees were used in the experiment, one in each plot, to provide better representation and reliability of LWD, since this is a complex measure and depends not only on the weather conditions but also on their interaction with the structure, composition, and physiology of the crop canopy (MAGAREY, 1999; MADEIRA et al., 2002; SENTELHAS et al., 2005; MARTA et al., 2007).

Eight plots of $20 \mathrm{~m}$ in width and length totaling an area of $400 \mathrm{~m}^{2}$ each were determined. Thus, there was sufficient distance between Electronic trees not to interfere in data collection. Four split plots were defined within the plots to evaluate Asian rust, enabling a greater distribution of sampling points. Treatments recommended for the soybean crop, except for disease control, were adopted as necessary. After the first symptoms of Asian rust was observed, weekly evaluations of the incidence (\%) and severity (\%) were made at four random points in the split plot, using a diagrammatic scale proposed by GODOY et al. (2006). At each point, four folioles were randomly assessed in the middle third of the plant, totaling 16 folioles per split plot and 64 folioles in the plot. Meteorological data and the severity of Asian rust were analyzed by descriptive statistics, by calculating the mean, standard deviation, and coefficient of variation (Table 1).

From the data collected in the two harvests, simulations were completed with the disease forecast models proposed by Reis et al. (2004) and Del Ponte et al. (2006b). The models used were designed as "site specific," being fed with local weather conditions, and were used at the crop level. The model described by Reis et al. (2004) generates infection probability data or daily values of probability of infection (DVPI) and was used to indicate the appearance of the first symptoms of Asian rust in the field. The DVPI are generated from data of temperature and LWD, resulting in values from 0 to 3 ( $0=$ absence of lesions; $1=0.1$ to $3 ; 2=3.1$ to $6 ; 3=6.1$ to $\left.9 \mathrm{~cm}^{-2}\right)$, which were converted to severity ( $0=$ absence of severity; $1=$ 0.76 to $23.1 \% ; 2=23.8$ to $46.2 \% ; 3=46.9$ to $69.2 \%$ severity). According to those authors, data on the Asian rust response were generated under controlled conditions, where external factors, such as viability of spores and different availabilities of inoculum, were minimized. For practical application under field conditions, which are influenced by different external factors, one should use the sum of DVPI (SDVPI) to reduce the negative effect of these in the prediction of infection. To implement the calculations of SDVPI, mean data on air temperature and LWD were inserted in formulas created in Excel, 7 days after the detection of $P$. pachyrhizi uredospores. 
Table 1. Descriptive statistics of the severity of Asian soybean rust (\%), mean temperature (T), and mean relative humidity (RH), in the 2011/2012 and 2012/13 harvests in Londrina, PR.

\begin{tabular}{ccccccc}
\hline & \multicolumn{3}{c}{ Harvest 2011/2012 } & \multicolumn{3}{c}{ Harvest 2012/2013 } \\
& Mean & s & CV & Mean & s & CV \\
\hline Severity of Asian rust & & & & & & \\
1 & 0.01 & 0.01 & 0.77 & 0.26 & 0.45 & 1.73 \\
2 & 0.20 & 0.06 & 0.32 & 0.95 & 0.58 & 0.61 \\
3 & 0.37 & 0.04 & 0.11 & 2.97 & 1.85 & 0.62 \\
4 & 0.45 & 0.12 & 0.26 & 6.19 & 2.26 & 0.36 \\
5 & 1.18 & 0.37 & 0.32 & 29.39 & 3.83 & 0.13 \\
6 & 3.39 & 1.31 & 0.39 & - & - & - \\
Meteorological data ${ }^{2}$ & & & & & & \\
T ( $\left.{ }^{\circ} \mathrm{C}\right)$ & 24.14 & 1.57 & 0.06 & 23.31 & 1.47 & 0.06 \\
RH (\%) & 79.05 & 8.76 & 0.11 & 85.37 & 6.00 & 0.07 \\
LWD (h) & 13.25 & 2.88 & 0.22 & 14.97 & 3.76 & 0.25 \\
\hline
\end{tabular}

$\mathrm{s}=$ standard deviation; $\mathrm{CV}=$ coefficient of variation; ${ }^{1}$ Values collected in $32 \mathrm{plots} ;{ }^{2}$ values collected in eight plots.

The model of Del Ponte et al. (2006b) proposes four equations generated from correlation analyses to identify variables associated with the final disease severity of Asian rust, and precipitation variables were more strongly correlated than the variables of temperature. The four equations used were based on four precipitation values: rain accumulated in one month (Rain ${ }_{\text {Acc }}$ ); rain accumulated in 1 month squared (Rain ${ }_{\text {Acc }}{ }^{2}$ ); days with rain above $0 \mathrm{~mm}$ in a month (Rain ${ }_{\text {Nod; } 0}$ ); and days with rain above $1 \mathrm{~mm}$ in a month (Rain ${ }_{\text {Nod; } 1}$ ). The equations used were

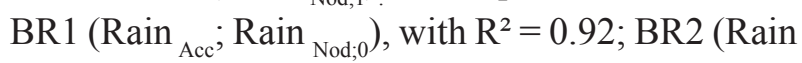
Acc), with $\mathrm{R}^{2}=0.90$; BR3 (Rain ${ }_{\text {Acc }}$; Rain ${ }_{\text {Acc }}^{2}$ ), with $\mathrm{R}^{2}=0.93$; and BR4 (Rain ${ }_{\text {Nod; } 1}$ ), with $\mathrm{R}^{2}=0.86$. The model was used following the observation of Asian rust symptoms in the plot.

\section{Results and Discussion}

Descriptive statistical analysis (Table 1) showed that the variables measured during the two harvests displayed a low coefficient of variation, and on average, the 2012/2013 harvest was exposed to lower temperature, higher air moisture, and greater LWD than the 2011/2012 harvest. On December 22, 2011, the first uredospores of the fungus $P$. pachyrhizi were captured by the SIGA spore trap, when the soybean was at stage V8. Based on their detection, and using the meteorological data collected, the model described by Reis et al. (2004) was applied for the next 7 days (Table 2). The SDVPI calculated was 9 units, and no Asian rust symptoms were observed in subsequent days. According to the model validation described by Juliatti et al. (2006), SDVPI close to 15 units can be taken to indicate the emergence of the first Asian rust lesions under field conditions, regardless of the cultivar.

Weather conditions on the day of uredospore detection (Table 2) generated DVPI = 1, indicating low favorability for infection of the plant by $P$. pachyrhizi. In addition, the precipitation recorded following the detection of uredospores was 3.3 $\mathrm{mm}$. It is possible that the uredospores were not present in sufficient quantity and quality to initiate the infection. Del Ponte (2006) and Canteri et al. (2007) reported that rain has a strong influence on the epidemic of Asian rust; however, in addition to the weather and the environment, disease progress is also strongly influenced by the amount of the initial inoculum, which explains the large variation observed in the severity of the disease after early or late sowing. 
Table 2. Mean temperature (T), mean relative humidity (RH), precipitation (Prec.), leaf wetness duration (LWD), sum of the daily values of the probability of infection (SDVPI) and soybean stage, December 22-28, 2011 in Londrina PR.

\begin{tabular}{|c|c|c|c|c|c|c|}
\hline Day & $\mathrm{T}\left({ }^{\circ} \mathrm{C}\right)$ & RH (\%) & Prec. $(\mathrm{mm})$ & LWD (h) & SDVPI & Stage \\
\hline $22 / 12$ & 26.4 & 67.2 & 0 & 11.9 & 1 & V8 \\
\hline $23 / 12$ & 26.2 & 70.5 & 0 & 11.7 & 1 & V8 \\
\hline $24 / 12$ & 26.1 & 70.6 & 0 & 11.4 & 1 & V8 \\
\hline $25 / 12$ & 24.1 & 81.0 & 3.3 & 14.8 & 2 & V8 \\
\hline $26 / 12$ & 24.1 & 71.8 & 0 & 13.3 & 2 & V8 \\
\hline $27 / 12$ & 25.3 & 69.1 & 0 & 11.9 & 1 & V8 \\
\hline $28 / 12$ & 26.0 & 70.6 & 0 & 10.9 & 1 & V8 \\
\hline Mean & 25.5 & 71.5 & - & 12.3 & - & - \\
\hline Total & - & - & 3.3 & - & 9 & - \\
\hline
\end{tabular}

Another factor that may have hampered disease occurrence was the soybean being in the vegetative stage (V8). According to Rupe and Sconyers (2008), rust lesions are not found on soybean until flowering, unless high levels of inoculum are present in the environment during the vegetative stage. This can occur because of the greater probability of infection when the canopy closes and creates a microclimate favorable for the maintenance of moisture, and uredospores are protected against ultraviolet radiation in the lower portions of the plant. The lesions may be formed at any stage of development, but a large increase of in disease incidence does not occur until canopy closure.

On January 9, 2012, Uredospores os $P$. pachyrhizi were detected in the experiment for the second time during in the harvest, with soybeans in the R1/R2 stage. In the 7 days following uredospore detection (Table 3 ) the model described by Reis et al. (2004) indicated SDVPI $=13$, which is close to 15 units, representing the value validated by Juliatti et al. (2006). On January 16, the first symptoms of Asian rust were observed in the experiment. After the detection of uredospores on day 9 , it rained for 4 consecutive days, totaling $80 \mathrm{~mm}$ (Table 3), which generated temperature, relative humidity, and LWD conditions that were sufficient to infect the soybean. Del Ponte (2006) confirmed the importance of rain in the development of the epidemic, which explains more than $85 \%$ of the variation of the maximum severity of Asian rust, contributing to the extension of the leaf wetness duration, reduction in temperature inside the canopy, and release of uredospores from the uredia.

During the 2012/2013 harvest, the first $P$. pachyrhizi uredospores were detected on January 15,2013 , with DVPI $=2$, increasing to 3 units on the day following detection as a result of $59 \mathrm{~mm}$ of rain (Table 4). On January 21, 2013, the first symptoms of Asian rust were detected in the field. In the 7 days following day 15, it rained $66.5 \mathrm{~mm}$, and the soybean was in the reproductive stage (R5.2). The rain was sufficient to provide conditions for the development of rust in plants, with a calculated SDVPI $=15$, representing the same value as found by Juliatti et al. (2006). The results obtained in São Paulo and Mato Grosso States (DEL PONTE et al., 2006a) indicated that there was a higher probability of disease occurrence when the SDVPI reached values of 30 to 45 units. 
Table 3. Mean temperature (T), mean relative humidity (RH), precipitation (Prec.), leaf wetness duration (LWD), sum of the daily values of the probability of infection (SDVPI), and soybean stage, January 9-15, 2012 in Londrina - PR.

\begin{tabular}{ccccccc}
\hline Day & $\mathrm{T}\left({ }^{\circ} \mathrm{C}\right)$ & $\mathrm{RH}(\%)$ & Prec. $(\mathrm{mm})$ & LWD $(\mathrm{h})$ & SDVPI & Stage \\
\hline $9 / 1$ & 24.3 & 72.1 & 0 & 9.1 & 1 & $\mathrm{R} 1$ \\
$10 / 1$ & 23.4 & 76.2 & 0 & 9.7 & 1 & $\mathrm{R} 2$ \\
$11 / 1$ & 23.6 & 87.0 & 22 & 14.2 & 2 & $\mathrm{R} 2$ \\
$12 / 1$ & 20.1 & 95.6 & 18.5 & 23.8 & 3 & $\mathrm{R} 2$ \\
$13 / 1$ & 20.3 & 95.4 & 27 & 22.9 & 3 & $\mathrm{R} 2$ \\
$14 / 1$ & 24.4 & 89.6 & 12.5 & 14.3 & 2 & $\mathrm{R} 2$ \\
$15 / 1$ & 25.2 & 84.2 & 0 & 10.8 & 1 & $\mathrm{R} 2$ \\
Mean & 23.0 & 85.7 & - & 15.0 & - & - \\
Total & - & - & 80.0 & - & 13 & - \\
\hline
\end{tabular}

Table 4. Mean temperature (T), mean relative humidity (RH), precipitation (Prec.), leaf wetness duration (LWD), sum of the daily values of the probability of infection (SDVPI), and soybean stage, January 15-21, 2013 in Londrina - PR.

\begin{tabular}{ccccccc}
\hline Day & $\mathrm{T}\left({ }^{\circ} \mathrm{C}\right)$ & RH $(\%)$ & Prec. $(\mathrm{mm})$ & LWD $(\mathrm{h})$ & SDVPI & Stage \\
\hline $15 / 1$ & 23.0 & 86.6 & 1 & 15.2 & 2 & R5.2 \\
$16 / 1$ & 21.0 & 91.7 & 59 & 20.0 & 3 & R5.2 \\
$17 / 1$ & 22.7 & 86.1 & 0 & 15.4 & 2 & R5.2 \\
$18 / 1$ & 23.7 & 83.1 & 0 & 13.5 & 2 & R5.2 \\
$19 / 1$ & 24.4 & 82.4 & 6.5 & 14.5 & 2 & R5.2 \\
$20 / 1$ & 23.3 & 81.5 & 0 & 12.2 & 2 & R5.2 \\
$21 / 1$ & 22.0 & 78.6 & 0 & 11.7 & 2 & R5.2 \\
Mean & 22.9 & 84.3 & - & 14.6 & - & - \\
Total & - & - & 66.5 & - & 15 & - \\
\hline
\end{tabular}

With regard to the sum of DVPI at the end of the harvests, one can observe that during the 2011/2012 harvest the SDVPI was 88 units at 43 days, while in the 2012/2013 harvest, the SDVPI was 67 units at 25 days. The second harvest accumulated proportionally more DVPI in and in less time, resulting in a higher rust severity. However, more studies should be conducted using the SDVPI for Asian rust, calculating the value that would represent an epidemic or the final severity of this disease.

In the two harvests, from the moment at which the first symptoms were detected to the end of the grain fill, the model described by Del Ponte et al. (2006b) was applied to estimate the final disease severity of soybean Asian rust (Table 5). The harvest period of 2011/2012 lasted for 43 days, with $124 \mathrm{~mm}$ of rain, mean temperature of $24^{\circ} \mathrm{C}$, mean relative humidity of $80.1 \%$, and mean LWD of $13.2 \mathrm{~h}$. During the first season, none of the equations used to estimate the severity attained similar values to those observed in the experiment, which was of $3.39 \%$. The equation used to estimate the lowest severity was BR1, with a final value of $26.2 \%$ (Table 5). As the model is climactic and does not monitor $P$. pachyrhizi uredospores in the field, it may overestimate the final severity in cases where there are low amounts of inoculum. Reis (2009) reported that few prediction models monitor the inoculum, and relate it to the beginning of disease development, for being very laborious. The majority of available systems are based on the meteorological requirements for the multiplication of inoculum and infection. 
Table 5. Severity estimated by the model of Del Ponte (2006), using four equations based on precipitation data, in two agricultural harvests (2011/12 and 2012/13) in Londrina- PR.

\begin{tabular}{cccc}
\hline \multirow{2}{*}{ Equations } & \multirow{2}{*}{$\mathrm{R}^{2}$} & \multicolumn{2}{c}{ Estimated final severity (\%) } \\
\cline { 3 - 4 } & 0.92 & $2011 / 2012$ & $2012 / 13$ \\
\hline BR1 & 0.90 & 26.2 & 81.0 \\
BR2 & 0.93 & 29.5 & 80.2 \\
BR3 & 0.86 & 30.7 & 87.0 \\
BR4 & 0.90 & 33.7 & 64.7 \\
\hline Mean & & 30.0 & 78.2 \\
\hline
\end{tabular}

Another factor that may justify the low Asian rust severity during the first harvest was the 14 days' drought period in January, following the onset of the disease in the field. Even in days without rain, leaf wetness sensors registered a mean $12.3 \mathrm{~h} \mathrm{LWD}$, resulting from the formation of dew. Currently, although there are various sensor models, the majority of models measures only the presence of leaf wetness, and do not quantify the percentage (GUEDES et al., 2013). According to Igarashi et al. (2014), much is said about LWD, but the measurement of leaf wetness percentage is more important because sensors that detect only the presence of water may overestimate the leaf wetness when this occurs at low rates. In this study, only the presence of leaf wetness was considered, and the percentage was not measured.

In the 2012/2013 harvest, the period from the first rust symptoms to the end of the grain filling lasted 25 days, with $255 \mathrm{~mm}$ of rain, a mean temperature of $22.9^{\circ} \mathrm{C}, 85.7 \%$ mean relative humidity, and 15.1 mean hours of LWD, with the final rust severity of $29.4 \%$ in the field. As in the previous harvest, the model described by Del Ponte et al. (2006b) overestimated the final disease severity, and the lowest value calculated by the equations was $64.7 \%$ (Table 5). In the study by Del Ponte et al. (2006a), the BR1 equation tended to overestimate the severity when the disease was lower than $30 \%$, which was observed for the four equations in this work in the two harvests.

The model described by Reis et al. (2004) provided a good indicator for the appearance of the first Asian rust symptoms when used with spore traps such as the SIGA spore trap. The first symptoms of Asian rust in the first and second harvest were observed only when the model of Reis et al. (2004) indicated SDVPI values close to 15 units. The four equations of the model proposed by Del Ponte et al. (2006b) overestimated the final rust severity in the two harvests assessed. The difficulty of implementing meteorological models, as assessed in this study, seems to lie in the absence of the pathogenic factor in the equations, mainly regarding the identification, quantification, and qualification of inoculum.

\section{Acknowledgments}

The authors thank CAPES-Coordination for the Improvement of Higher Education Personnel for providing a doctoral scholarship to the first author.

\section{References}

ALVES, S. A. M.; FURTADO, G. Q.; BERGAMIN FILHO, A. Influência das condições climáticas sobre a ferrugem da soja. In: ZAMBOLIM, L. (Ed.). Ferrugem asiática da soja. Viçosa, MG: Universidade Federal de Viçosa, Departamento de Fitopatologia, 2006. p. 37-59.

BERGAMIN FILHO, A. Curvas de progresso da doença. In: AMORIM, L.; REZENDE, J. A. M.; BERGAMIN FILHO, A. Manual de fitopatologia: princípios e conceitos. 4. ed. Piracicaba: Ceres, 2011. v. 1, p. 647666.

BONDE, M. R.; BERNER, D. K.; NESTER, S. E.; FREDERICK, R. D. Effects of temperature on urediniospore germination, germ tube growth, and 
initiation of infection in soybean by Phakopsora isolates. Phytopathology, Saint Paul, v. 97, n. 8, p. 997-1003, 2007.

CANTERI, M. G.; TSUKAHARA, R. Y.; SILVA, O. C. Monitoramento das variáveis ambientais para controle da ferrugem asiática da soja. In: CONGRESSO BRASILEIRO DE FITOPATOLOGIA, 40., 2007, Maringá. Resumos... Brasília: SBF, 2007. v. 32, p. 65-66.

DEL PONTE, E. M. Retrospectiva e tendências em modelagem matemática e previsão de ferrugem asiática. Revista Plantio Direto, Passo Fundo, RS, v. 96, n. 1, p. 21-30, nov./dez. 2006.

DEL PONTE, E. M.; GODOY, C. V.; CANTERI, M. G.; REIS, E. M.; YANG, X. B. Models and applications for risk assessment and prediction of Asian soybean rust epidemics. Fitopatologia Brasileira, Brasília, v. 31, n. 6, p. 533-544, 2006 a.

DEL PONTE, E. M.; GODOY, C. V.; LI, X.; YANG, X. B. Predicting severity of Asian soybean rust with empirical rainfall models. Phytopathology, Saint Paul, v. 96, n. 7, p. 797-803, 2006 b.

DEL PONTE, E. M.; MARTINS, E. J.; ESKER, P. D.; GODOY, C. V. Modelagem e previsão de epidemias de ferrugem asiática da soja - avanços na teoria e aplicação. In: WORKSHOP DE EPIDEMIOLOGIA DE DOENÇAS DE PLANTAS, 2., 2007, Campos do Jordão. Resumos... Campos do Jordão, 2007. p. 28-35.

EMPRESA BRASILEIRA DE PESQUISA AGROPECUÁRIA - EMBRAPA. Centro Nacional de Pesquisa de Solos (Rio de Janeiro, RJ). Sistema brasileiro de classificação de solos. Rio de Janeiro: EMBRAPASPI, 2009.

GARCÉS, F. R. A ferrugem asiática da soja causada por Phakopsora pachyrhizi Sydow e Sydow. Artículo de Revisión-Ciencia y Tecnología, Quevedo, v. 4, n. 2, p. 45-60, 2011.

GARDIANO, C. G.; BALAN, M. G.; FALKOSKI FILHO, J.; CAMARGO, L. C. M. de; OLIVEIRA, G. M. de; IGARASHI, W. T.; SUDO, L. T.; IGARASHI, S.; ABI SAAB, O. J. G.; CANTERI, M. G. Manejo químico da ferrugem asiática da soja, baseado em diferentes métodos de monitoramento. Arquivo Instituto Biológico, Campinas, v. 77, n. 3, p. 497-504, 2010.

GODOY, C. V.; KOGA, L. J.; CANTERI, M. G. Diagrammatic scale for assessment of soybean rust severity. Fitopatologia Brasileira, Brasília, v. 31, n. 1, p. 63-68, 2006.

GUEDES, A. L.; MOREIRA, M.; FRANÇA, M. B. D. E. M.; FRANÇA, J. A. de; PIAI, J. C.; AGUIAR E SILVA, M. A. de; CANTERI, M. G. A distributed and wireless data acquisition system to fight against sugarcane orange rust. Controle \& Automação, Campinas, v. 65, n. 1, p. $1-13,2013$.

IGARASHI, S.; BALAN, M. G. Ferrugem na soja. Direto do Vale, Assis, v. 1, n. 3, p. 1-8, 6 ago. 2004.

IGARASHI, W.T.;AGUIARESILVA, M.A.; IGARASHI, S.; ABI SAAB, O. J. G.; FRANÇA, J. A. Duração e porcentagem de molhamento foliar determinados pelo espaçamento entrelinhas, e influência sobre a ferrugem asiática da soja. Summa Phytopathologica, Botucatu, v. 40, n. 2, p. 123-127, 2014.

INSTITUTO AGRONÔMICO DO PARANÁ - IAPAR. Médias Históricas-1976/2015. Londrina: Iapar, 2015. Disponível em: <http://www.iapar.br/arquivos/Image/ monitoramento/Medias_Historicas/Londrina.htm $>$. Acesso em: 14 abr. 2016.

ITO, M. F.; MIRANDA, M. A. C.; BRAGA, N. R.; MIRANDA, F. T. S. Ocorrência de ferrugem em soja, nos compostos IAC, macho-estéreis, em Campinas-SP. In: REUNIÃO DE PESQUISA DE SOJA DA REGIÃO CENTRAL DO BRASIL, 24., 2002, Londrina. Anais... Londrina: Embrapa Soja, 2002. p. 165.

JULIATTI, F. C.; REIS, E. M.; OCCHIENA, E. M.; SILVA JÚNIOR, J. L; MOURA, E. A. C.; POLIZEL, A. C. Validação de um modelo climático de alerta da ferrugem asiática da soja e determinação de danos baseados na incidência foliolar e severidade sob inoculação artificial. In: REUNIÃO DE PESQUISA DE SOJA DA REGIÃO CENTRAL DO BRASIL, 28. 2006, Londrina. Resumos... Londrina: Embrapa Soja: Fundação Meridional: Fundação Triângulo, 2006. D 08, p. 150-152. (Documentos, 272).

MADEIRA, A. C.; KIM, K. S.; TAYLOR, S. E.; GLEASON, M. L. A simple cloud-based energy balance model to estimate dew. Agricultural and Forest Meteorology, Amsterdam, v. 111, n. 1, p. 55-63, 2002.

MAGAREY, R. D. A theoretical standard for estimation of surface wetness duration in grape. 1999. Dissertation (Thesis Ph. D.) - Cornell University, Ithaca, New York.

MARTA, A. D.; MAGAREY, R. D.; MARTINELLI, L.; ORLANDINI, S. Leaf wetness duration in sunflower (Helianthus annuus): analysis of observations, measurements and simulations. European Journal of Agronomy, Amsterdam, v. 26, n. 3, p. 310-316, 2007.

MELCHING, J. S.; DOWLER, W. M.; KOOGLE, D. L.; ROYER, M. H. Effects of duration, frequency, and temperature of leaf wetness periods on soybean rust. Plant Disease, St. Paul, v. 73, n. 2, p. 117-122, 1989.

MOREIRA, M.; FRANCA, M. B. M.; FRANCA, J. A.; GUEDES, A. L.; CANTERI, M. G.; SILVA, M. A. A. 
E. Árvore eletrônica para estudo da duração do período de molhamento foliar. In: CONGRESSO BRASILEIRO DE AGROINFORMÁTICA, 8., 2011, Bento Gonçalves. Anais... Bento Gonçalves: RBIAgro, 2011. p. 1-5.

REIS, E. M. Critérios baseados em sistemas de aviso: modelo climático. In: REIS, E. M. (Org.). Critérios indicadores do momento para aplicação de fungicidas visando ao controle de doenças em soja e trigo. Passo Fundo: Aldeia Norte, 2009. p. 103-109.

REIS, E. M.; SARTORI, A. F.; CAMARA, R. K. Modelo climático para a previsão da ferrugem da soja. Summa Phytopathologica, Botucatu, v. 30, n. 2, p. 290-292, 2004.

RUPE, J.; SCONYERS, L. Soybean rust. The plant health instructor. St. Paul: American Phytopathological Society, 2008. Available at: <http://www.apsnet.org/ idcenter/intropp/lessons/fungi/Basidiomycetes/Pages/ SoybeanRust.aspx $>$. Accessed at: 12 out. 2014.
SENTELHAS, P. C.; GILLESPIE, T. J.; BATZER, J. C.; GLEASON, M. L.; MONTEIRO, J. E. B. A.; PEZZOPANE, J. R. M.; PEDRO, M. J. Spatial variability of leaf wetness duration in different crop canopies. International Journal of Biometeorology, New York, v. 49, n. 2, p. 363-370, 2005.

YORINORI, J. T.; PAIVA, W. M.; FREDERICK, R. D.; COSTAMILAN, L. M. Epidemics of soybean rust (Phakopsora pachyrhizi) in Brazil and Paraguay from 2001 to 2003. Plant Disease, St. Paul, v. 89, n. 6, p. 675$677,2005$.

YORINORI, J. T. Ferrugem da soja: panorama geral. In: MOSCARDI, F. In: WORD SOYBEAN RESEARCH CONFERENCE, INTERNATIONAL SOYBEAN PROCESSING AND UTILIZATION CONFERENCE, CONGRESSO BRASILEIRO DE SOJA, 7; 4; 3., 2004, Foz do Iguaçu. Proceedings... Foz do Iguaçu: Anais, 2004. v. 26, p. 1299-1307. 
